species is evidently not as local as our previous account suggested.

Short-tailed Weasel: On July 24 E.O.H. had a brief view of the rear half of one disappearing under one of the buildings at the Margaret Lake Fish
Camp. As its black tail tip was clearly seen it could not have been a Least Weasel and the area is well beyond the range of the Long-tailed Weasel.

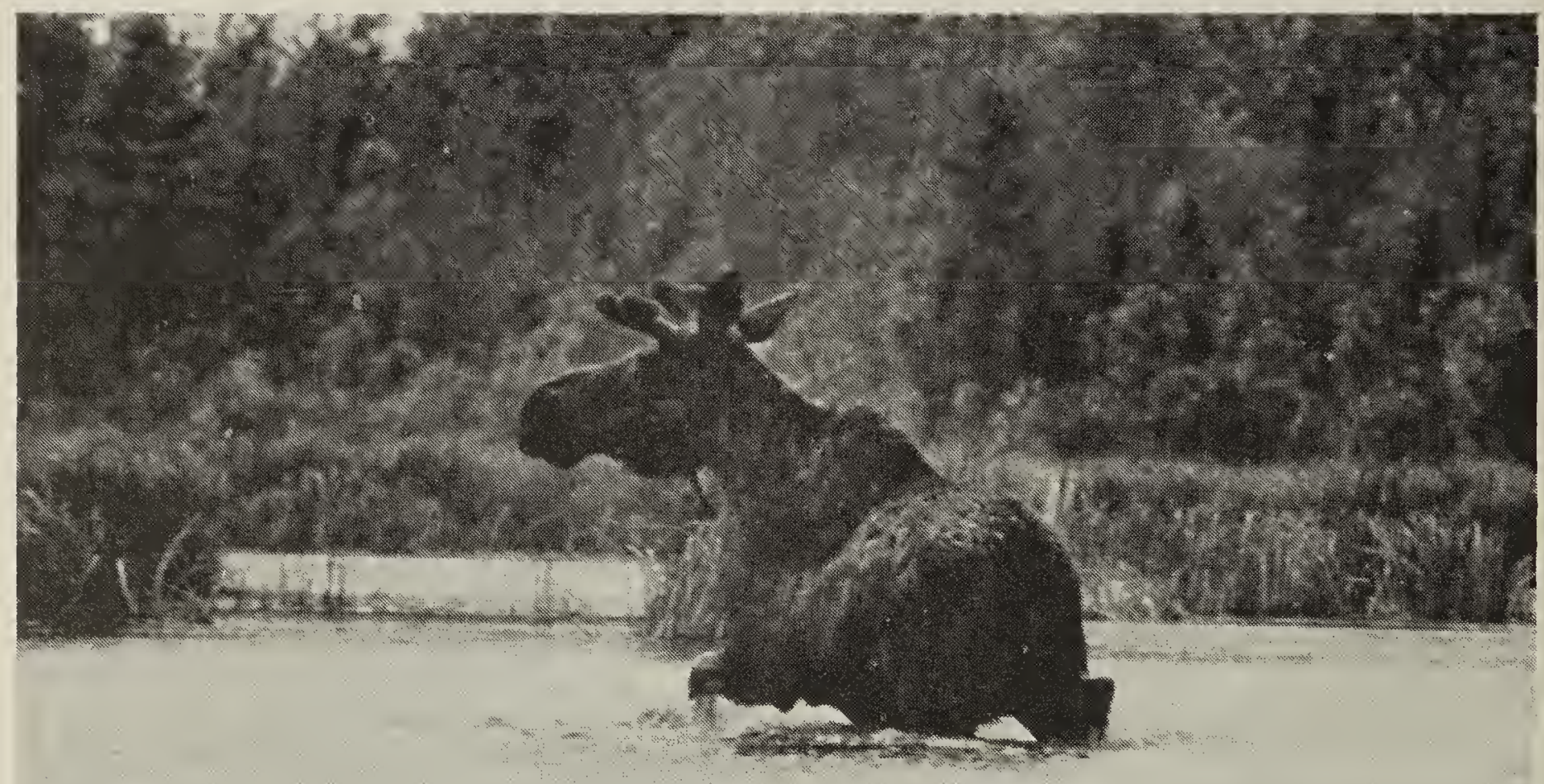

\title{
SASKATCHEWAN CHRISTMAS MAMMAL COUNT - 1975
}

Compiled by WAYNE C. HARRIS, Box 93, Raymore, Sask., S0A 3 J0.

Mild weather resulted in excellent coverage of the province, with 28 localities reporting, compared to only 16 last year. The number of species was also up from 15 species last year to 23 species this year. Counts taken in or near the forest edge resulted in several new species (Gray Wolf, Moose, and Woodland Caribou). Unusual was a
Franklin's Ground Squirrel (a species which normally hibernates), seen near Asquith. The warm weather may account for this.

Populations in general appear to be remaining rather stable, with possibly the exception of the Lynx. This year it was reported only once, compared to two last year, and the coverage this 
sə!วəds jeןloL

noq!.eว рuвıром

วsoow

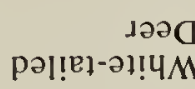

دәәС әाпW

วu!dnวง০d

əsnow əsnoH

נอג׳รกพ

әЮ м мореәW

ds əsnow

ןas!nbs pay

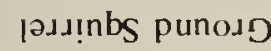

s U! !Yueda

I!

әมеH әочSMOUS

I!qqеу хое

рәเ!อ।-วเ! $M$

xuК T

yunys pad!lus

צบ! W

อระว

рә|!อา-ชิน⿰า

-ds jәsеวм

HOM KEבD

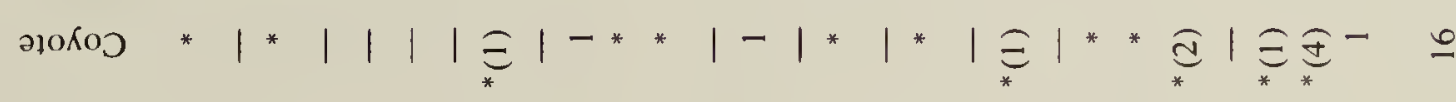

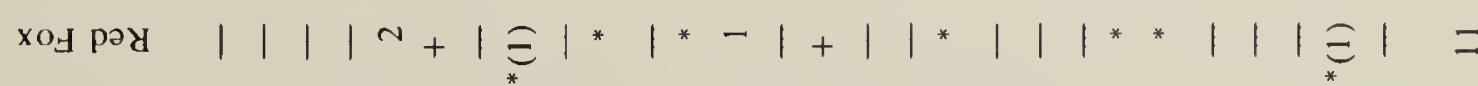

ds xasos $|1| 1|1| 1|1-1| 1|1| 1|1| 1|1| 1 \mid 1$ -

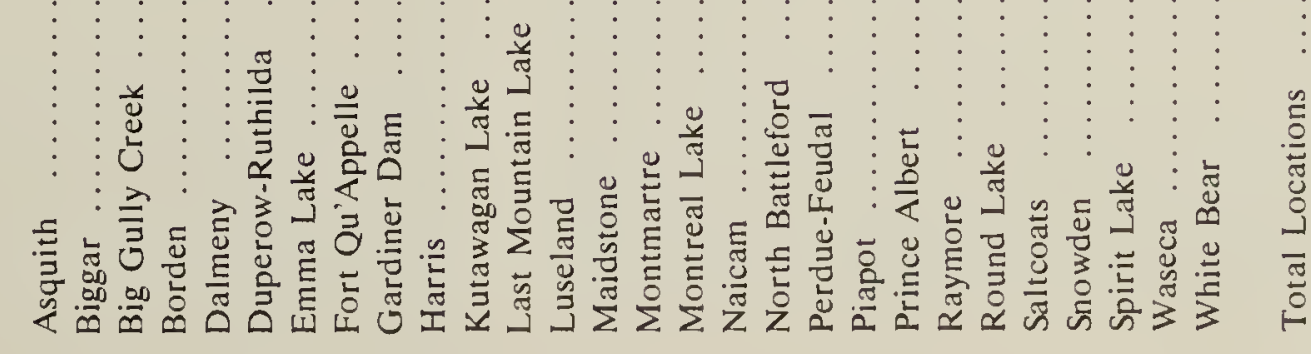


year was almost double last year's, with some counts in good areas for this species.

For weather, coverage and participants, please refer to Christmas Bird Counts elsewhere in this issue. Mouse tracks, even though identified to species, have been recorded under Mouse.
Symbols found in the table are as follows:

* Identified by tracks, with the number of animals by tracks in parenthesis.

+ Seen during count period but not on count day.

D Freshly dead animal seen.

\section{HITCH-HIKING MARMOTS}

By KEITH SHAW, Cardston, Alta.

In June, 1969, I was driving with Don Shaw of Cardston, Alberta, on Going-To-The-Sun Highway in Glacier National Park, Montana. We had stopped just above the Weeping Wall to look at a large Whistling Marmot (Marmota caligata) by the road edge. We were distracted for a moment while getting out camera gear and when we looked for the marmot it was gone. Concluding that it had gone into a burrow since the weather was chilly, we left the area and continued without stops across Logan Pass and down the east side to Rising Sun Campground where we began to prepare lunch. A piercing whistle from beneath the car sent us to check the engine compartment for mechanical failure. Under the hood near the engine was the large marmot from the Weeping Wall, apparently unhurt but also unwilling to leave. We tried to dislodge it but then decided it would be best to finish our lunch and drive the hitch-hiker back across Logan Pass to where we had picked it up. Several whistles later and just as we were about to leave, the marmot voluntarily dropped to the ground and was last seen under a California-licensed minibus. This marmot had ridden 15 miles under our car.
Several days later I learned of a Cardston farmer who had made the same Weeping Wall stop in 1968 and had then driven directly home with only a brief stop at the Carway Customs. Shortly after arrival in Cardston a Whistling Marmot was noticed on the ground under the car. It was chased out and went directly under the farmer's truck where it disappeared in the engine compartment. Later that day the truck was driven north on the Blood Indian Reserve and parked. Shortly thereafter the marmot left the truck and ran into a grain field. This animal had travelled under two vehicles a total of 60 miles.

District Ranger Robert Frauson of Glacier National Park, Montana, reported the following incident. ${ }^{3} \mathrm{~A}$ government truck stopped in front of an apartment in the St. Mary Ranger Station housing area where a very hot and panting Whistling Marmot fell out from the engine compartment. Karen Frauson put the marmot in a box and took it into the shady woods to allow the animal to cool. She checked about a half hour later but the marmot was dead. It did not seem to be hurt and apparently died of the heat. Late June was very warm and engine heat would add to the marmot's thermal overload. 